\title{
Hvordan organisere et akuttilbud for ungdom i selvmordsrisiko?
}

\author{
Ved Lise Baklund, Kjetil Nilssen, Liv Ristvedt og Pål Zeiner
}

\begin{abstract}
De fleste som mottar et akutt tilbud i psykisk helsevern for barn og unge henvises med bakgrunn i bekymring rundt selvmordsrisiko. Ved BUPA Ungdomsseksjonen for øyeblikkelig hjelp i Drammen er behandlingstilbudet organisert slik at disse ungdommene kan følges opp ambulant eller poliklinisk. Artikkelen beskriver gjennom case og data innhentet i MAP-studien (Ruud et al., 2006) hvordan prinsipper som tilgjengelighet, fleksibilitet og kontinuitet utgjør grunnlaget for denne praksisen.
\end{abstract}

\section{ABSTRACT}

Selvmordsrisiko er en av de vanligste grunnene til henvisning til psykiatriske akuttavdelinger for ungdom. Ved Ungdomsseksjonen for $\varnothing$ yeblikkelig hjelp i Drammen har en gjennom flere år arbeidet med fleksible løsninger for ungdom med akutt selvmordsrisiko. Behandlingen kan skje gjennom innleggelse, polikliniske samtaler eller ambulante tiltak. I 2005 deltok seksjonen i Multisenterstudien for akuttpsykiatri (MAP-studien). Sentrale spørsmål i studien var: Hva kjennetegner pasientene? Hvilken sammenheng er det mellom vurdert selvmordsrisiko og valg av behandlingsnivå? Hvordan operasjonalisere prinsippene tilgjengelighet, fleksibilitet, kon tinuitet, familie og nettverk i behandlingen av unge mennesker i selvmordsrisko? Her presenteres noen av dataene seksjonen samlet inn under MAP studien, samt hovedprinsippene som er fulgt, illustrert med ulike case. Artikkelen beskriver hvordan man kan gi et poliklinisk/ambulant tilbud til ung dom med forhøyet selvmordsrisiko.

Suiciderisk among adolescents - how to help in an acute phase and after

Risk of suicide is one of the most frequent reasons for psychiatric referrals of patiens between 13-18 years in the Child and Adolescent Mental Health Services (CAMHS). The clinical picture is compound and hetero-geneous because psychiatric symp tomes are less marked than in adults and phenomenons like insecurity, unstability and impulsivnes are more common. In 2005, Ungdomsseksjonen for $\varnothing$ yeblikkelig hjelp, an acute emergency unit for adolescents, participated in a multi-centre study of five acute CAMHS. The study clarified some of the principles of intervention and the article presents theese principles illustrated with cases and with data collected in the multicentre study. The service is organised in a unit providing both outpatient (home treatment or consultation with therapists) and inpatient treatment. Mobilising parents and relatives based on a familiy- and network therapeutic approach, is fundamental in the treatment irrespective of where the patient recieves the treatment. The organization of the psychiatric emergency services to children and adolescents should aim for flexibility and availability and offer both inpatient and out-patient treatment. In this way one can adjust the service by severity of mental illness and in cooperation with and support from the family and the network.

LEVERT: $\quad$ 15/03-12 REVIDERT: $\quad 11 / 11-12$ AKSEPTERT: 22/11-12

\section{Selvmordsrisiko hos ungdom og hjelp i akuttfasen}

Tristhet og depresjon, ofte med selvmordstanker eller risiko for selvmord, er en av de vanligste grunnene til henvisning til spesialisthelsetjenesten for ungdommer i aldersgruppen 13-18 år (Sintef, 2009). Noen av utfordringene ved vurdering av selvmordsrisiko hos ungdom er at det kliniske bildet varierer betydelig. Hos noen er selvmordstanker- og handlinger del av bildet ved alvorlig psykiatrisk lidelse som for eksempel schizofreni eller affektiv lidelse (Grøholt, 2007). Andre ungdommer får akutte selvmordstanker utløst av kjærlighetssorg, fall i skoleprestasjoner, konflikter med familie, venner eller annet. For en del ungdommer handler selvmordstanker- og handlinger også om kommunikasjon og fors $\varnothing \mathrm{k}$ på problemløsning i forhold til viktige personer i omgivelsene (Snoek, 2002). Fenomener som lav selvfølelse, ambivalens og impulsivitet er vanlige i ungdomsalderen samtidig som det kan være en del av det kliniske bildet ved selvmordsrisiko. Eksperimentering med ulike rusmidler forekommer ofte som en del av ungdomskulturen samtidig som det utgjør en sentral risikofaktor for selvmordsatferd (Kvalem og Wichstrøm 2009, Schilling et al., 2009). Ved selvmordsrisiko er det som oftest et samspill mellom ytre stress i form av en utløsende hendelse og en personlig sårbarhet hos den unge (Hestetun, 2006).

I løpet av de senere år er det kommet flere rapporter om forståelse og behandling av pasienter med selvmordsrisiko (Kunnskapssenteret, nr. 24-2006 og nr. 7-2007). De fleste studier og rapporter tar for seg forebygging av selvmordsrisiko hos voksne. Få studier vurderer hvordan akuttilbudet for ungdom i selvmordsrisiko bør utformes. Tilbudet bør tilpasses den enkelte pasient, type og omfang av aktuelle selvmordsrisiko, type psykiatrisk lidelse, risiko- og beskyttelsesfaktorer, familie og nærmiljø og andre faktorer (Sosial- og helsedirektoratet, 2008). Det finnes ikke sikre anbefalinger om behandlingsmetoder i den subakutte fasen for behandling av ungdom med suicidalrisiko (Hawton, 2005). Oppsummert forskning viser at ambulant og nærmiljøbasert behandling kan være virksomt spesielt i behandling av barn og unge med atferdsvansker og antisosial atferd, mens ambulant behandling av barn og unge med akutt selvmordsrisiko er mangelfullt dokumentert (Kunnskapssenteret, 2006, Shepperd et al., 2009). En tilpasset dialektisk atferdsterapi (DBT-A) for suicidale ungdommer for å redusere selvskadende atferd er utviklet og virker lovende (Miller et al., 2007). En norsk RCT-studie av denne behandlingsvarianten til ungdom med gjentatt villet egenskade pågår og vil forhåpentligvis kunne avklare hvorvidt DBT-A er effektiv (Haga og Mehlum, 2010). En kvasi-eksperimentell studie av dialektisk atferdsterapi viste at ungdom med ustabile personlighetstrekk, som fikk slik behandling, hadde færre innleggelser på sykehus innenfor psykisk helsevern sammenlignet med en gruppe tilsvarende ungdommer som fikk individuell psykodynamisk behandling og familieterapi en gang pr. uke. Videre opplevde gruppen, som fikk DBT, en reduksjon av selvmordstanker og psykiatriske symptomer. Det var ikke signifikant reduksjon i antall selvmordsfors $\varnothing \mathrm{k}$ (Rathus og Miller, 2002). Om dette tilbudet også egner seg ved akutt suicidalrisiko hos ungdom er, så langt vi vet, ikke systematisk unders $\varnothing \mathrm{kt}$.

I hverdagen ved en akuttpsykiatrisk seksjon for ungdom vil en stor del av arbeidet bestå i løpende vurderinger av suicidalrisiko og gjennomf $\varnothing$ ring av behandlingsprogram både i akutt og subakutt fase, samt legge til rette for videre oppfølging i primær- eller spesialisthelsetjenesten. 


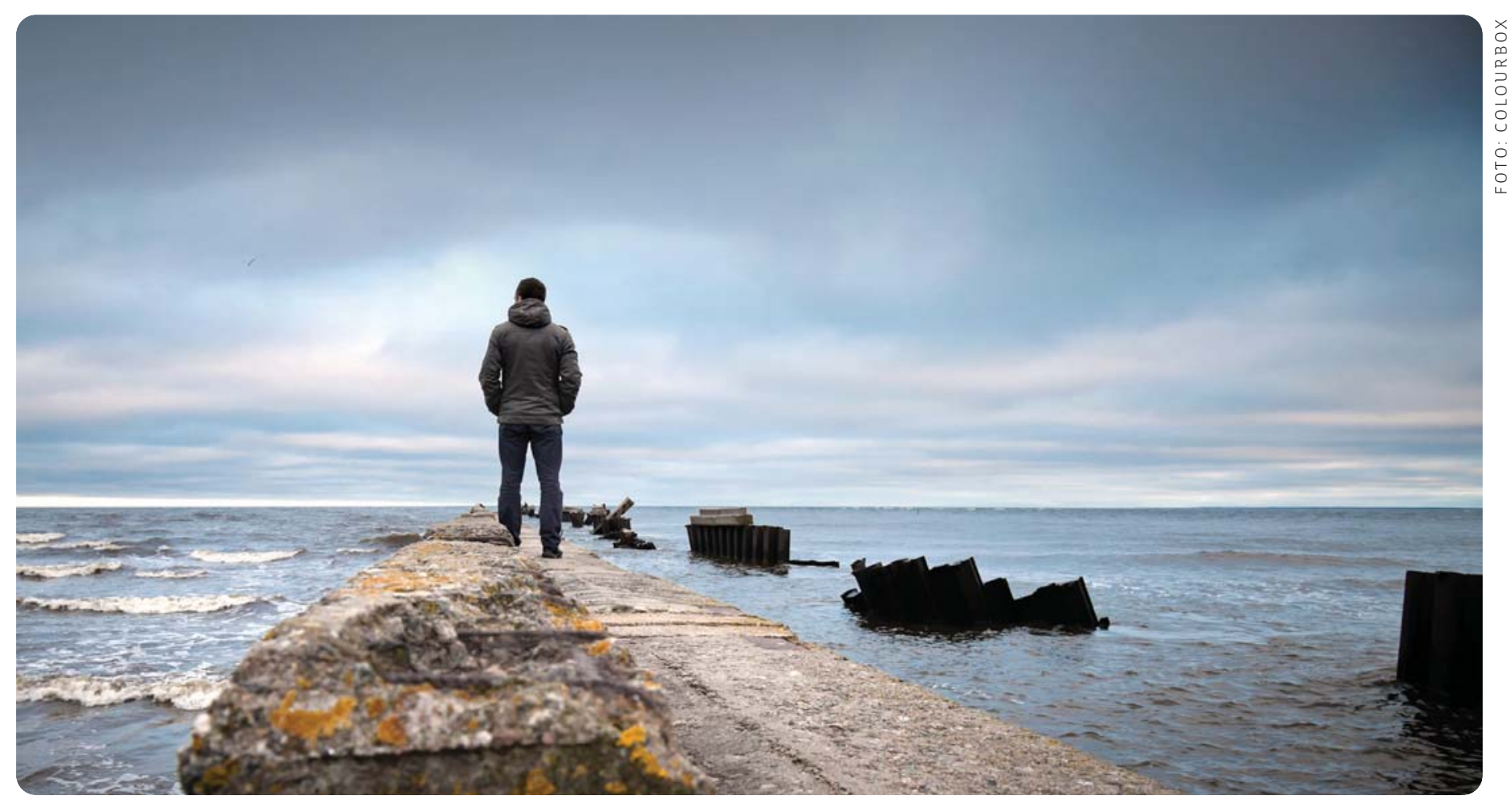

Aktuelle spørsmål i akuttfasen er: Hvem er i så stor risiko at de trenger døgninnleggelse med kontinuerlig tilsyn? Hvem kan behandles gjennom et ambulant eller intensivt poliklinisk tilbud? Hva slags oppfølgingsprogram er best egnet i akuttfasen for både dem som innlegges og dem som behandles utenfor døgnavdelingen? Hva slags kontakt skal det være fra ungdom og foreldre til akuttseksjonen dersom det oppstår forverring? Hvor lenge og hvordan bør man følge opp etter akuttfasen? Det finnes ikke klare svar i eksisterende retningslinjer eller kliniske studier på disse spørsmålene, som fagfolk i akuttenhetene må ta løpende beslutninger omkring.

I 2005 ble Multisenterstudien (MAP. studien) gjennomf $\varnothing \mathrm{rt}$ av Evalueringsnettverket for akuttpsykiatri med st $\varnothing t t e$ fra Sosial- og helsedirektoratet (Sintef, 2005). Tilsammen deltok 19 psykiatriske akuttavdelinger for voksne, ni akutteam for voksne og fem akuttenheter for ungdom. Sentrale spørsmål i studien omhandlet hva som kjennetegnet de ulike akuttpsykiatriske tilbudene og variasjonen innen disse, hva som kjennetegnet pasienter som henvises til de ulike typene akuttpsykiatriske tilbud, hva slags behandling pasientene fikk samt utfallet av behandlingen. Unders $\varnothing$ kelsen ble godkjent av Regional komité for medisinsk forskningsetikk, Øst-Norge, 2004 (ref. nr. 211-04049) og Datatilsynet (ved Norsk samfunnsvitenskapelig datatjeneste, 2004, prosjekt nr. 11074). Sosialog helsedirektoratet gav dispensasjon fra taushetsplikten for utlevering av informasjon fra helsetjenestene. I denne studien ble det rapportert om selvmordstanker eller -planer hos $58 \%$ av ungdommene som ble tatt imot for akuttvurdering (Ruud et al., 2006). Blant de fem akuttavdelingene for ungdom skilte vår seksjon seg ut gjennom å gi behandlingstilbud på ulike behandlings- eller omsorgsnivåer: samtaler i poliklinikken, hjemmebehandling eller innleggelse. Ved å se på dataene innhentet fra egen seksjon $\varnothing$ nsket vi å besvare følgende spørsmål: Hvem er pasientene som mottas for $\varnothing$ yeblikkelig hjelp? Hvordan er vurderingen av selvmordsrisiko med på å avgjøre valg av behandlingsnivå? Hvordan operasjonalisere prinsippene tilgjengelighet, fleksibilitet, kontinuitet, familie og nettverk i behandlingen av unge mennesker i selvmordsrisiko? Dataene presenteres sammen med ulike case, som er med på å gi mer utfyllende beskrivelser av pasientgruppen samt hvilke faktorer som kan være førende i valget av behandlingsnivå.

\section{Ungdomsseksjonen for øyeblikkelig hjelp i Drammen}

Ungdomsseksjonen gir tilbud gjennom intensiv poliklinisk behandling, ambulante tilbud eller innleggelse. Henvisninger som krever $\varnothing$ yeblikkelig-hjelpvurdering, kommer vanligvis fra helsetjeneste, barnevern eller andre offentlige instanser, men ungdommen selv eller pårørende kan også henvende seg direkte. Seksjonen har 24 timers vaktordning med team bestående av lege og erfaren milj $\varnothing$ - og familieterapeut. Personalgruppen er tverrfaglig sammensatt. Alle har spesiell opplæring og kompetanse i vurdering og håndtering av ungdom i selvmordsrisiko. Arbeidstiden for seksjonens ansatte er delt mellom døgnenheten og den polikliniske og ambulante virksomheten. Seksjonen har 2-3 døgnplasser tilgjengelig ved behov for innleggelse. 
I slike situasjoner vil ofte én av foreldrene bo i eget rom på døgnenheten. Mobilisering av foreldre og pårørende, basert på en familie- og nettverksterapeutisk tilnærming, er grunnleggende i behandlingen uavhengig av behandlingsnivå (Ristvedt, 2006). Dette innebærer at foreldrene inntar en aktiv rolle både ved innleggelser og ved poliklinisk/ambulant oppfølging.

I MAP-studien ble alle nye pasienter i 2005 registrert. Ungdomsseksjonen i Drammen registrerte således data fra 80 pasienter som hadde i alt 119 behandlingsepisoder i løpet av 2005. Av disse 119 episodene var 96 klassifisert som “фyeblikkelig hjelp", og disse er lagt til grunn for analysene under. Alle 80 pasienter hadde minst én behandlingsepisode klassifisert som " $\varnothing$ yeblikkelig hjelp”, og alle 80 pasienter er dermed inkludert. Et eget skjema ble utviklet for MAP-studien og ble utfylt av ansvarlig behandler. Dette inneholdt i tillegg til data fra journal, mer detaljert informasjon om henvisning, psykiske vansker og behandling og inkluderte også data skåret i henhold til en graderingsskala for selvmordsrisiko. Skalaen ble utviklet i fellesskap av erfarne klinikere fra de fem ulike akuttavdelingene som deltok i den nasjonale prosjektgruppen i MAPstudien. Skalaen angir fem nivåer av selvmordsrisiko fra ingen eller lav risiko (ingen tanker eller planer om selvmord) til høyere risiko (utført selvmordsfors $\varnothing \mathrm{k}$ før henvisning).

De aller fleste ( $85 \%$ ) pasientene registrert som behandlet ved Ungdomsseksjonen var i aldersspennet 15-18 år og 75 \% var jenter. Hos 75 \% var henvisningsgrunnen selvmordsrisiko. Dette er en høyere andel enn i det totale MAP. materialet, men det har trolig sammenheng med at det ble brukt ulike inklusjonskriterier. Mens Ungdomsseksjonens tall kun tok utgangspunkt i de sakene som omhandlet фyeblikkelig hjelp, inkluderer MAP-studien (alle fem akuttavdelingene) alle nye saker, også de som ikke var klassifisert som $\varnothing$ yeblikkelig hjelp. Siden Ungdomsseksjonen har ulike behandlingsnivåer, $\varnothing$ nsket vi å unders $\varnothing$ ke likheter og forskjeller mellom døgnepisoder og polikliniske episoder.
Et nytt pasientforl $\varnothing \mathrm{p}$ ble registrert for hvert skifte i behandlingsnivå. Av 80 pasienter var det 62 som kun hadde én behandlingsepisode. Det vil si at de kun var innlagt eller kun var i et poliklinisk opplegg i 2005. Av de 80 var det imidlertid 19 pasienter som skiftet behandlingsnivå én eller flere ganger i løpet av 2005. Disse 19 pasientene skiftet fra enten først å være innlagt til så å gå over i et poliklinisk/ambulant tilbud eller motsatt. Blant de 96 behandlingsepisodene var 35 døgnepisoder og 62 polikliniske episoder.

Når det gjaldt selvmordsrisiko, var det rapportert ingen selvmordstanker eller - planer hos 16,7 \%, mens det var angitt passive $d \varnothing \mathrm{d} \varnothing \varnothing$ nsker hos $12,5 \%$, tanker om å ta sitt eget liv uten konkrete planer hos 39,6 \%, konkrete selvmordsplaner hos $14,6 \%$ og ha gjort selvmordsfors $\varnothing \mathrm{k}$ f $\varnothing \mathrm{r}$ inntak hos $13,5 \%$. I de resterende 3,1\% var selvmordsrisikoen ukjent.

Kategorien ukjent gjelder episoder hvor selvmordsrisiko ikke ble vurdert, enten fordi dette ikke var en aktuell problemstilling eller av andre grunner. Vi unders $\varnothing$ kte hvordan selvmordsrisiko fordelte seg på de 35 døgnepisodene og de 62 polikliniske episodene.

Av 35 døgnepisodene fant vi at 11,4\% ble vurdert ikke å være i selvmordsrisiko, 45,7\% hadde tanker om å ta sitt eget liv, men ikke konkrete planer. Hos 25,7 \% av de innlagte forelå det konkrete planer og hos 14,3 \% var det gjort selvmordsfors $\varnothing \mathrm{k}$ f $\varnothing \mathrm{r}$ inntak. Hos de resterende 2,9 $\%$ var selvmordsrisikoen rapportert som ukjent. Av de 62 polikliniske episodene var 39,4 \% vurdert ikke å være i selvmordsrisiko, 36,1 \% hadde tanker om å ta sitt eget liv, men ikke konkrete planer, Hos 8,2 \% forelå det konkrete planer og hos $13,1 \%$ var det gjort selvmordsfors $\varnothing \mathrm{k}$ før inntak. De resterende 3,2\% var ukjent. Hovedtendensen var at det oftere ble valgt døgnbehandling der det forelå $\phi \mathrm{kt}$ selvmordsrisiko. I tilfeller hvor det forelå konkrete planer om selvmord så det ut til å være mest vanlig å gi døgnbehandling, men i tilfeller der det var gjort selvmordsfors $\varnothing \mathrm{k}$ f $\varnothing \mathrm{r}$ inntak fant vi en ganske lik fordeling av poliklinisk behandling og døgnbehandling.
Våre data gir ikke grunnlag for å anbefale et behandlingstilbud fremfor andre, men supplert med beskrivelser av sentrale behandlingsprinsipper og hvordan disse er operasjonalisert, vil vi kunne gi et grunnlag for videre hypoteser, som kan testes ut prospektivt. Prinsippene som beskrives og illustreres under med case, er seksjonens faglige behandlingsprinsipper og har vært førende for hvordan seksjonen er organisert (få døgnplasser, fleksibelt turnusarbeid, vaktordning, delt arbeidstid mellom poliklinikk og døgnenhet). Prinsippene er ikke unike for Ungdomsseksjonen, men går igjen i flere nasjonale retningslinjer og sentrale helsepolitiske dokumenter (Helse- omsorgsdepartementet 1996/1997, 1997/1998, Kunnskapssenteret, nr 22-2006).

\section{Tilgjengelighet}

Helsesøster på en videregående skole tar kontakt med seksjonen etter en samtale med Petter, 16 år. I samtalen har det kommet frem at han hadde tenkt på ulike muligheter a ta sitt eget liv. Han benektet konkrete planer om selumord. Helsesøster lurer på om Petter er alvorlig deprimert og er usikker på hvor sterke selumordstankene er. Hun forteller at faren til gutten tok livet sitt $i$ fjor og at han har hatt det vanskelig det siste året hjemme og på skolen, noe som har gått utover konsentrasjonen og skoleprestasjoner. Petter går med på å komme til en vurdering ved seksjonen samme ettermiddag i følge med moren.

Ved akutte psykiske kriser er høy grad av tilgjengelighet for både pasienter, pårørende og de som henviser pasientene overensstemmende med de anbefalinger som gis i "Retningslinjer for forebygging av selvmord i psykisk helsevern" (Sosialog helsedirektoratet, 2008). I vårt tilfelle gir vaktordningen mulighet for at fastlege, legevakt, barnevernsleder eller andre som $\varnothing$ nsker å henvise kan ta direkte kontakt når som helst på døgnet. Også ungdommen selv eller foresatte oppfordres til å ta kontakt ved forverring av tilstanden eller usikkerhet omkring situasjonen de er i. 
Selv om henvendelser fra ungdom og foreldre ikke følger de vanlige veiene ved henvisninger til spesialisthelsetjenesten, kan det være riktig å åpne opp for direkte kontakt, særlig der motivasjonen for å søke hjelp er lav hos ungdommen selv (Ristvedt, 2006).

MAP-studien viste at 54,8 \% av henvisningene kom fra primær- eller spesialisthelsetjenesten, 10,3 \% fra barneverntjenesten, $17,5 \%$ fra foreldre og 17,3\% fra andre. Det ble gjort vurderinger av ungdommen samme dag som henvisningen kom hos $92 \%$, oftest ved konsultasjon, men noen ganger per telefonsamtale. Der hvor vurderingen skjedde senere enn henvisningsdag var dette avtalt med pasient og foreldre og funnet forsvarlig.

Etter et selumordsforsøk har Mari fått intensiv poliklinisk oppfølging på Ungdomsseksjonen sammen med foreldrene. Foreldrene opplevde at hun etter dette virket mer tilgjengelig. Hun snakket mer. En kveld oppdaget de imidlertid at hun ikke var på rommet sitt slik de trodde. Etter a ha ringt mobilen uten å få svar varslet de politiet og gikk ut for å lete. Etter en times leting $i$ nærområdet oppdaget de Mari gaiende langs veien. De ble bekymret fordi hun virket fraværende og ikke ville si noe om hvorfor hun hadde gått hjemmefra. De ringte Ungdomsseksjonen og fikk komme til vurdering samme natt. I denne samtalen kom det frem at Mari igjen hadde fått selumordstanker og hadde konkrete planer om å ta livet sitt. Mari ble lagt inn frivillig $i$ døgnavdelingen.

\section{Fleksibilitet}

Prinsippet om fleksibilitet tar utgangspunkt $\mathrm{i}$ at hjelpen som gis i størst mulig grad skal foregå der ungdommen og omsorgspersonene finner det hensiktsmessig. Med basis i den samlede faglige vurderingen og i dialog med familien avgjøres om og på hvilket nivå den aktuelle ungdommen og familien skal tilbys et behandlingsopplegg. Det kan enten være polikliniske samtaler ved Ungdomsseksjonen med og uten foreldre, inntil flere ganger per uke, ved ambulant terapi, som foregår der hvor pasienten til vanlig bor og oppholder seg, eller ved innleggelse. Denne fleksibiliteten gjør det mulig for pasienten og familien i st $\varnothing$ rst mulig grad å opprettholde vanlige aktiviteter, noe som er forbundet med raskest mulig symptomreduksjon og bedring av funksjon.

Av pasienter som deltok i studien ble $67,7 \%$ behandlet med et poliklinisk eller ambulant tilbud uten innleggelse, mens 32,3 \% ble innlagt i døgnavdelingen. Som beskrevet var det en tendens til at alvorligere suicidalrisiko medførte hyppigere behov for innleggelse, men også pasienter med forhøyet selvmordsrisiko (konkrete planer eller fors $\varnothing \mathrm{kt}$ selvmord før inntak) kunne behandles hjemme med god st $\varnothing$ tte fra pårørende og hyppig kontakt med Ungdomsseksjonen. Videre fant vi en tendens til at akuttvurderinger på dagtid sjeldnere førte til innleggelse (21,8\%), sammenliknet med når vurderingene ble gjort på ettermiddag/kveld eller natt (45,2 \%). Dette kan ha sammenheng både med tilstandsbildet, med tilgjengelighet av ulike hjelpeinstanser og andre forhold.

Fra å være åpen, aktiv, sosial og utadvendt, ble Stian mer innadvendt og isolerte seg mer og mer på rommet sitt foran PCen. Han sluttet å gå på skolen, var oppe på nettene og brydde seg ikke lenger om å dusje. Da en kamerat varslet foreldrene om Stians selvskading og foreldrene fant en kniv under puta hans, kontaktet de fastlegen som henviste dem til Ungdomsseksjonen hvor de fikk en vurdering samme dag. Det ble vurdert at Stians symptomer kunne være forenlig med en prodromaltilstand og mulig fare for utvikling av psykose. Foreldrene til Stian ønsket at Stian skulle være hjemme siden de kunne følge ham opp selv på dagtid. Om natten opplevde de større utrygghet og det ble derfor utplassert en nattevakt fra Ungdomsseksjonen $i$ hjemmet, som var tilgjengelig for Stian og avlastet familien.

\section{Kontinuitet}

Den relasjonen som er etablert mellom ungdom, familie og terapeut i krisesituasjonen, oppleves av mange som viktig blant annet fordi mange av ungdommene vi møter har opplevd relasjonsbrudd, frykter avvisning fra andre og strever med fortrolighet.
Om ungdommen skulle oppleve forverring og må innlegges, møter han eller hun det samme behandlingsteamet i døgnenheten som i poliklinikken. Behandlingskontakten avsluttes heller ikke brått når krisen anses som over ved at pasienten overføres til poliklinisk behandling et annet sted. Så lenge ungdommen eller familien opplever at det er nødvendig, gis tilbud om behandling fra Ungdomsseksjonen. Gjennomsnittlig varighet for alle behandlingsepisoder var 79 dager og $90 \%$ av episodene hadde en behandlingsvarighet på syv måneder.

Sofie bor på en barnevernsinstitusjon. Hun har hatt gjentatte selumordsfors $\emptyset k$ hwor hun har hoppet fra høyder, tatt piller og kuttet seg. Sofie har hatt kontakt med Ungdomsseksjonen $i$ over et år og følges opp med polikliniske samtaler en gang per uke, $i$ perioder oftere. Barnevernsinstitusjonen, Ungdomsseksjonen og Sofie er enig om at innleggelser bør unngås, og de har laget en egen avtale for situasjoner når hun har det som vanskeligst. Her er roller og ansvar fordelt for å forebygge og minimalisere krisene nair de oppstår.

\section{Involvering av ungdom, familie og nettverk}

Konkrete og åpne spørsmål om selvmordstanker og -planer hos ungdommen danner utgangspunkt for samtalene hvor også foreldre eller nærmeste pårørende deltar. I samtalene og vurderingene legges det eksplisitt vekt på hvor bekymret det er grunn til å være for alle de impliserte parter og hvordan en kan forholde seg både til pasienten og overfor hverandre i familien. Den psykologiske betydning av at man opplever at de nærmeste bryr seg og har omsorg samtidig som de passer på, oppfatter vi som vel så effektivt for å redusere risikoen for nye selvmordsforsøk som en innleggelse. Spфrsmål om hvordan det hadde vært for foreldrene om sønnen eller datteren hadde tatt livet sitt, gir ofte sterke vitnesbyrd om hvor umistelig ungdommen er for foreldrene. Dette aktualiserer tilknytningen i familien og styrker følelsesmessige bånd, som er viktig i arbeid for forebygging av nye selvmordsfors $\varnothing \mathrm{k}$. 


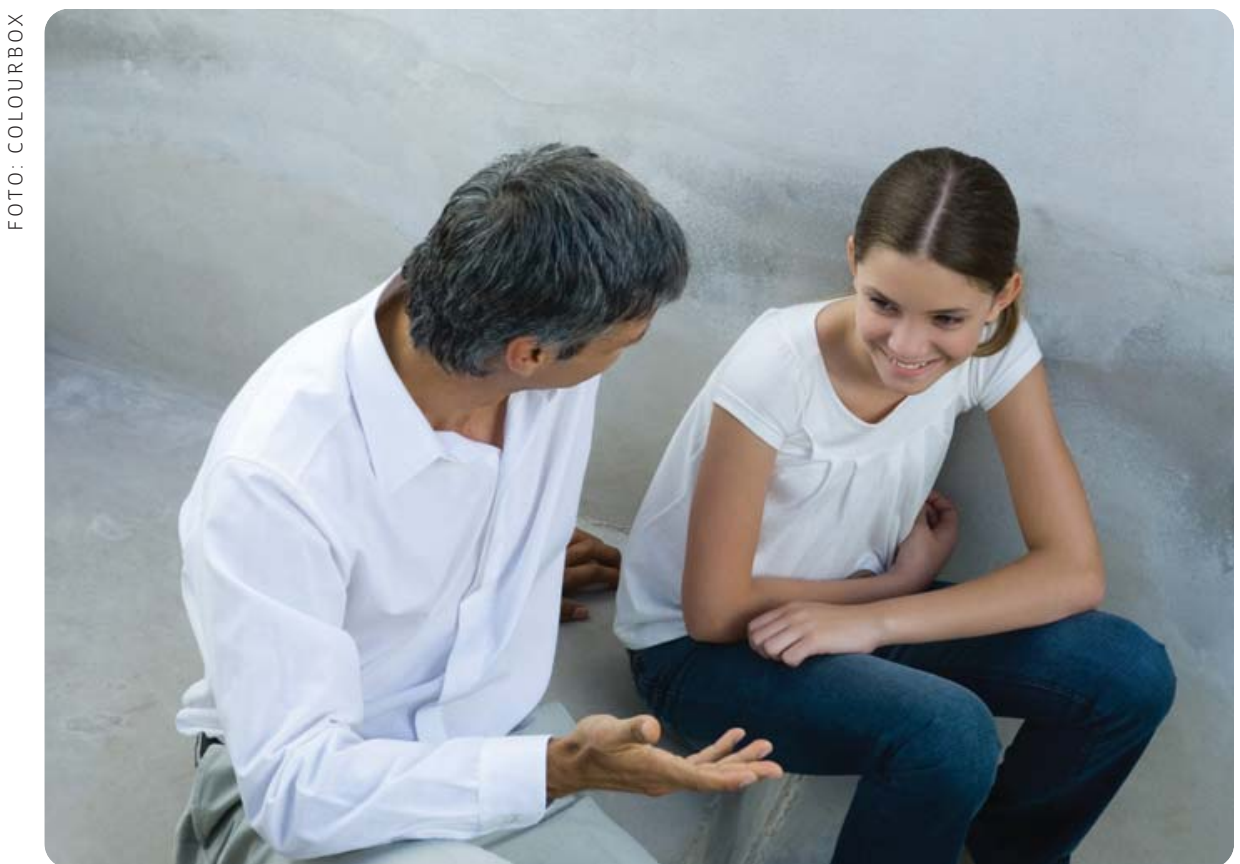

Som et tryggingstiltak hender det at foreldre må være hjemme på heltid for en periode for å ivareta barnet sitt. På samme måte som foreldre med alvorlig somatisk syke barn får pleiepenger og sykemeldes for å ivareta egne barn, har også foreldre til barn som har en alvorlig psykisk lidelse og er i selvmordsrisiko, rett til å motta pleiepenger. Etter stadfestelsen av grunn til bekymring dreier samtalen seg over på beskyttelsestiltak de første timene eller det første døgnet. Her skisseres og drøftes alternative behandlingsløsninger for familien.

Etter foreldrenes skilsmisse og brudd med kjæresten opplevde Kristine at verden falt $i$ grus. Kristine ble funnet av stemoren sin etter en overdose piller og brakt til sykehus hvor hun fikk nødvendig behandling. Ungdomsseksjonen ble kontaktet. I samtalen med Kristine og foreldrene kom det frem at hun etter foreldrenes skilsmisse opplevde at foreldrene ikke lenger brydde seg om henne. Tilknytning til foreldrene ble et viktig samtaleemne. Foreldrenes samarbeidsevner, som var svekket etter skilsmissen, ble styrket $i$ et felles prosjekt idet de måtte gå sammen om a planlegge og sikre omsorgen for datteren sin, time for time konkretisert gjennom skriftlig avtale.

\section{Oppsummering og diskusjon}

Våre data gir ikke grunnlag for å si om den ene behandlingsformen er mer effektiv enn den andre. I og med at de fleste henvendelsene gjaldt selvmordsrisiko, vil fokus være å legge til rette for en behandling som ivaretar sikring mot selvmord. Ingen av pasientene tok sitt eget liv i løpet av behandlingsepisodene eller, så langt vi har direkte eller indirekte kunnskap om, etter utskrivelse. Selv om mange av pasientene lot seg behandle poliklinisk er ikke døgnplasser for ungdom i psykisk krise overflødige eller uegnet. I akutte kriser med selvmordstanker vil en viktig vurdering være om pasientens sikkerhet er godt nok ivaretatt. Der en vurderer at selvmordsrisikoen er overhengende, at nettverket rundt ungdommen er tynt eller behovet for skjerming og beskyttelse er så stort at opphold i hjemmet ikke synes tilstrekkelig, vil en innleggelse være n $\varnothing$ dvendig og det eneste forsvarlige for å sikre liv og helse.

Den st $\varnothing$ rste gruppen av pasienter i vårt materiale var jenter i 15-årsalderen som rapporterte selvmordstanker. Det er et tankekors at det synes vanskeligere å nå gutter som i ungdomsårene får selvmordstanker som del av en depresjon eller som reaksjon på en hendelse. Hos gutter i denne alderen er selvmord 3-6 ganger hyppigere enn hos jenter (Grøholt et al. 1997). Denne utfordringen løses ikke av akuttenheter eller helsevesenet alene. Her må det sannsynligvis inn mer informasjon til ungdom, foreldre, skole og andre som ser ungdommen ofte for at akuttpsykiatriske tilbud skal komme til anvendelse i st $\varnothing$ rre grad for denne gruppen. Vår studie har flere metodologiske svakheter ved at den kun presenterer funn fra én seksjon, og den sier ikke noe om behandlingseffekter. Den kan imidlertid tjene til å belyse problemstillinger for videre studier. Det er komplisert å gjennomf $\varnothing$ re randomiserte kontrollerte studier innen akuttpsykiatri av etiske og faglige grunner. For å få mer kunnskap om pasientgruppen, hvilke behandlingsalternativer som egner seg best og hvordan tjenestetilbudet bør utformes, er det $\varnothing$ nskelig med mer systematisk prospektiv forskning. 
Vår erfaring er at det også er andre forhold som er av like stor betydning i valget mellom poliklinisk/ambulant behandlingsmetode og innleggelse. Kontekstuelle forhold som grad av støtte fra nærmeste pårørende, tillit mellom ungdommen, pårørende og behandlere, psykisk lidelse hos foreldre og betydningsfulle livshendelser påvirker også avgjørelsen om hvilken behandling som bør gis. Derfor bør videre unders $\varnothing$ kelser også fokusere på relasjoner mellom ungdommen og foresatte, grad av støtte og hjelp fra foresatte og samarbeidet mellom fagpersoner og ungdom/foresatte i фyeblikkelig hjelp-vurderingen. Kvalitative studier vil også lettere kunne gjennomføres innenfor rammene for akuttpsykiatri. Samtidig vil en kunne få $\varnothing \mathrm{kt}$ kunnskap om brukertilfredshet og opplevelse av tilbudene.

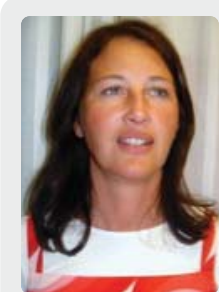

Lise Baklund er FoU. rådgiver, FoU-avdelingen, Klinikk for psykisk helse og rus, Vestre Viken HF. Filosof og familieterapeut. Flere års erfaring fra arbeid med ungdom i selvmordsrisiko og deres familier.
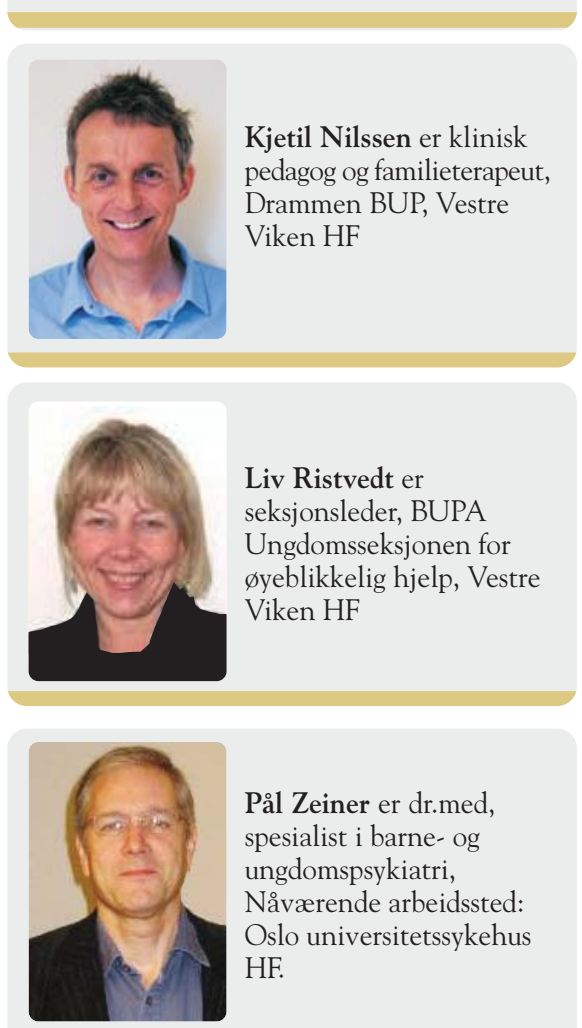

Pål Zeiner er dr.med, spesialist i barne- og ungdomspsykiatri, Nåværende arbeidssted: Oslo universitetssykehus HF.

\section{Referanser}

Grøholt, B., Ekeberg, Ø., \& Haldorsen, T. (2000). Adolescents hospitalized with deliberate selfharm: The significance of an intention to die. European Child and Adolescent Psychiatry, 9, 244-254.

Grøholt, B. (2007). Unge og gientatte selvmordsfors $\phi \mathbf{k}$. Suicidologi, 12(3), 8-11. Haga, E. og Mehlum, L. (2010). Pågående intervensjonsstudie for ungdom med gientatt villet egenskade. Suicidologi, 15(1), 12-13.

Hanssen-Bauer, K., Heyerdahl, S., Hatling, T., Jensen, G., Olstad, P.M., Stangeland, T. \& Tinderholdt, T. (2011). Admissions to acute adolescent psychiatric units. A prospective study of clinical severity and outcome. International Journal of Mental Health Systems, 5(1).

Hawton, K. (2005). Psychosocial treatments following attempted suicide: evidence to inform clinical practice. I Hawton, K. (ed.). Prevention and treatment of suicidal behavior: from science to practice. Oxford, UK: Oxford University Press. Helse- og omsorgsdepartementet (1996/1997). St meld nr 25, Åpenhet og helhet, Om psykiske lidelser og tjenestetilbudene. Oslo: Helse- og omsorgsdepartementet.

Helse- og omsorgsdepartementet (1997/1998). Opptrappingsplanen for psykisk helse.

1999-2006. Oslo: Helse- og omsorgsdepartementet.

Helse- og omsorgsdepartementet (2000). FOR 2000-12-21-1409 Forskrift om $\phi$ yeblikkelig hjelp i det psykiske helsevernet. Oslo: Helse- og omsorgsdepartementet.

Hestetun, I. (2006). Mфter med suicidale klienter $i$ en barne- og ungdomspsykiatrisk poliklinikk, Suicidologi, 11(3), 6-9.

Huey, S.J. Jr., Henggeler, S.W., Rowland, M.D., et al. (2004). Multisystemic therapy effects on attempted suicide by youths presenting psychiatric emergencies. Journal of the American Academy of Child \& Adolescent Psychiatry, 43, 183-90.

Jacobson CM., Gould M. (2007). The epidemiology and phenomenology of non-suicidal selfinjurious behavior among adolescents: a critical review of the literature. Arch Suicide Res 2007, 11(2), 129-47.

Kvalem, I.L., og Wichstrøm, L. (red.) (2009).

Ung i Norge, Psykososiale utfordringer.

Oslo: Cappelen Damm Akademisk.

Miller, A.L., Rathus, J.H., Linehan, M.M., (2007). Dialectical Behavior Therapy with Suicidal Adolescents. New York: Guilford Press.

Nasjonalt kunnskapssenter for helsetjenesten. Rapport Nr 22-2006. Ambulante psykiatriske helsetjenester til barn og ungdom som alternativ til institusjonsbehandling. Oslo.

Nasjonalt kunnskapssenter for helsetjenesten. Rapport Nr 24-2006. Forebygging av selvmord, del 1: Psykoterapi, medikamentelle intervensjoner og elektrokonvulsiv terapi. Oslo.
Nasjonalt kunnskapssenter for helsetjenesten. Rapport Nr 4-2007. Forebygging av selvmord, del 2. Oslo.

Rathus, J.H. \& Miller, A.L. (2002). Dialectical behavior therapy adapted for suicidal adolescents. Suicide and Life-Threatening Behavior, 32, 146-156.

Ristvedt, L. (2006). Ambulant og poliklinisk behandling som alternativ til innleggelse. En beskrivelse av $\phi$ yeblikkelig hjelp tilbudet ved BUPA Ungdomsenheten. I: Halvorsen, I., Ropstad, I., Rund, B. Rishovd, Seltzer, W.J. (red.). Foreldre og fagfolk i samspill. Behandling av psykiske vansker hos barn og unge (s. 187-199). Stavanger: Hertervig Forlag.

Ruud, T., Gråwe, R., Hatling, T. (2006). Akuttpsykiatrisk behandling i Norge - resultater fra en multisenterstudie. Trondheim: Sintef Helse.

Schilling, E. A., Aseltine Jr. R., H. Glanovsky, J. L., James, A., Jacobs, D. (2009). Adolescent Alcohol Use, Suicidal Ideation, and Suicide Attempts. Journal of Adolescent Health, 44 (4), 335-341.

Sintef (2005): http://www. sintef.no / Teknologi og samfunn / Helse / Helsetjenesteforskning / Psykisk helse / Akuttilbud / Forskning på akuttpsykiatriske tilbud og forl $\phi \mathrm{p} /$ Multisenterstudie av akuttpsykiatri - MAP 2005.

Sintef (2009). Samdata sektorrapport for det psykiske helsevernet 2008 2/2009. Trondheim: SINTEF Teknologi og samfunn, Helsetjenesteforskning.

Snoek, J. E., 2002. Ungdomspsykiatri. Oslo: Universitetsforlaget.

Sosial- og helsedirektoratet. (2008). Retningslinjer for forebygging av selvmord i psykisk helsevern. Oslo: Sosial- og helsedirektoratet.

Østlie, K., Reinholdt, N.P., Lindmark, J. (2012). Nasjonale retningslinjer for forebygging av selvmord i psykisk helsevern. Tilpasninger til målgruppen: barn/unge i spesialisthelsetjenesten. Suicidologi, 17(1), 13-15.

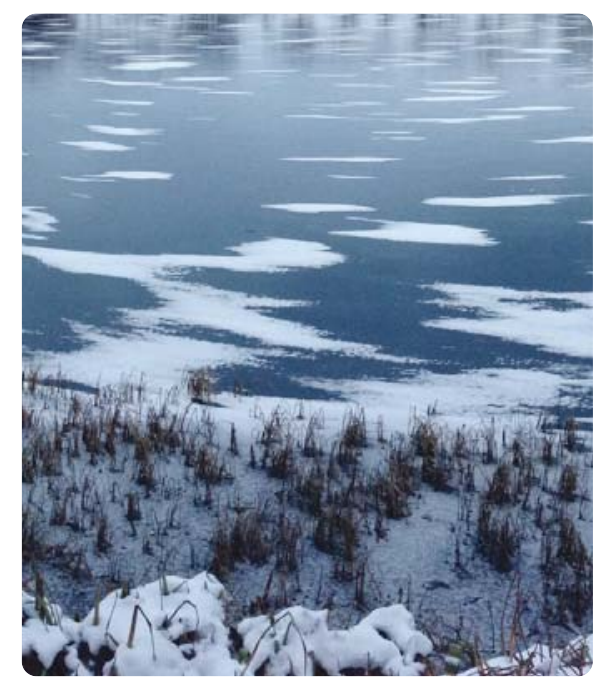

